\title{
Bacteriological Quality of Alternative Water Sources in Bambui and Bambili Residential Areas, North-West Region, Cameroon
}

\author{
Nchang Chrysanthus \\ Department of Medical Laboratory Sciences, Higher Institute of Biomedical Sciences, Bamenda University of \\ Science and Technology (BUST), Bamenda, Cameroon \\ Email: chrysanthusn@yahoo.com
}

Received 10 June 2014; revised 15 July 2014; accepted 20 August 2014

Copyright (C) 2014 by author and OALib.

This work is licensed under the Creative Commons Attribution International License (CC BY). http://creativecommons.org/licenses/by/4.0/

\section{(c) (i) Open Access}

\begin{abstract}
Bambui and Bambili residents collect water from different sources to fulfil their daily needs. Varieties of microbes exist in water including bacteria, algae, fungi, protozoa and viruses, where they form a complex ecosystem whose dynamics are usually difficult to comprehend. Those varieties of microbes play an important role for contamination of water and results in various outbreaks of diseases and death. The aim of this study is to evaluate the bacteriological quality of well and spring water sources in a residential area dominated by students. A total of 18 well water samples were randomly collected and subjected to bacteriological analysis; this is to trace the presence of pathogens indicators of faecal contamination. Analysis revealed that seventeen (17) of the eighteen wells were contaminated, with the open wells most contaminated, with some $>1100 \mathrm{CFU} / \mathrm{ml}$ of water samples. Klebsiella sp. was the most common bacterial species isolated in almost all the wells (but for 3 that showed no growth), while other bacteria included: Enterobacter sp., Salmonella sp., E. coli and Proteus mirabilis. Generally, results revealed that about $95 \%$ of well water samples tested are of low microbiological quality and so do not fulfil requirements of WHO standards for drinking water.
\end{abstract}

\section{Keywords}

Microbes, Drinking Water, Bambui and Bambili Residential Areas, Outbreak, Faecal Coliforms

Subject Areas: Ecosystem Science, Environmental Sciences

\section{Introduction}

Water is essential to sustain life and a satisfactory supply must be made available to consumers [1]. But in spite

How to cite this paper: Chrysanthus, N. (2014) Bacteriological Quality of Alternative Water Sources in Bambui and Bambili Residential Areas, North-West Region, Cameroon. Open Access Library Journal, 1: e649.

http://dx.doi.org/10.4236/oalib.1100649 
of the promises made during the last decade, and owing to the fact that the right to drinkable water is nowadays part of human rights, one-sixth of the world population still does not have access to safe drinking water [2] [3]. Water of adequate quantity and quality, is essential for healthy life. The associations between sanitation, water and health are well known. Many diseases are associated with contaminated water and water shortages. Without adequate water, people can neither clean themselves properly, nor their clothes, and their cooking utensils. Neither can food be prepared hygienically. Domestic water is generally supplied to homes through private wells/ springs/brooks or public water companies. Water supplied by public water companies is usually safe to drink and does not pose a health risk. The quality of the water supplied by these companies is periodically checked. Water supplied by a private source is also usually safe to drink, if infrastructural development is done following universal standards; however, it can be contaminated by harmful bacteria resulting from faulty septic tanks, chemicals from toxic spills that occurred years before, leaking underground storage tanks, or pesticides and fertilizers. Thus, the potability of privately owned water sources cannot be guaranteed since expertise in water infrastructure is usually lacking.

The chronic shortage of water in many developing countries has obliged the population to look for alternative sources, whose quality is usually not known and which have frequently been the source of waterborne epidemics. Human pathogenic microorganisms transmitted by water include: bacteria, viruses and protozoa. Most grow in the intestines and are passed out in faeces. Ideally, drinking water should not contain any pathogenic microorganism or bacteria indicative of faecal pollution. Since these microorganisms have been noted as indicators of faecal contamination, there is a need for continuous monitoring. Unavailability of municipal water supply (provided by $\mathrm{CDE}$ ) and lack of community water supply to the Bambui and Bambili residential area, resulting in the use of untreated well water sources is posing a great health risk to the members of this community. There have been a lot of complaints on health problems such as skin rashes, abdominal discomfort and others by students after using well water sources for drinking, bathing and other domestic purposes. Thus, the purpose of this study is to use bacterial counts to evaluate the microbial quality of water samples from wells and other sources in this residential area.

\section{Material and Methods}

SETTING: The study was carried out in the Bambui and Bambili residential areas, inhabited mainly by students. It is situated about $3 \mathrm{~km}$ from Bamenda: the capital city of North-West Cameroon. It is located in a valley surrounded by hills with cattle rearing taking place on the hill tops. As this cattle feed, they deposit their faeces as they move along. It displays a Guinean type equatorial climate with a regular and abundant rainfall of about $1800 \mathrm{~mm}^{3}$ per annum and average temperature of $25^{\circ} \mathrm{C}$.

\section{Collection of Water Samples}

Water samples from eighteen wells were randomly collected for bacteriological analysis. Also, water samples were collected from two springs and three brooks commonly used by the population of this areas. Water samples were collected in sterile bottles tied with a strong string to a piece of metal (about $400-500 \mathrm{~g}$ ) as the weight. The bottle cap was aseptically removed and the weighed bottle lowered into the well to a depth of about $1-2$ metres. The bottle was brought up to the surface and covered with a screw cap when no air bubbles were seen inside. For the springs and brooks, water was allowed to flow into clean bottles continuously until they were full (same procedures used by the population). The water was immediately transported in an ice container at $4^{\circ} \mathrm{C}$ to the laboratory for analysis. Water analysis was done following standard methods using the multiple tube fermentation technique.

\section{Identification of Isolates}

Positive tubes of the presumptive test were sub cultured on Eosin Methylene blue (EMB) agar for the enumeration of Escherichia coli and other enteric coliforms. All the inoculated media were incubated aerobically at $37^{\circ} \mathrm{C}$ for 48 hours, after which the isolates were further characterized by a combination of colonial and morphological characteristic on solid media and sub cultured on Klinger Iron agar (KIA) which showed distinctive characteristics on the butt, slope and hydrogen sulphite gas production. Nutrient agar plates were also prepared for all the eighteen samples to identify any Gram positive bacteria present. 


\section{Results}

Results obtained were analyzed and presented on tables and figures.

The Table 3 clearly indicates that open wells had greater number of bacterial contaminants, both in type and quantity. Proteus mirabilis was seen only in open wells (W18O). Klebsiella sp. and Salmonella sp. were the most abundant in both open and covered wells.

Faecal streptococci (Streptococcus fecalis) was isolated from nutrient agar plates of three covered well samples (W1C, W3C, and W15C), and also isolated from all the open well samples. The presumptive coliform count measured by the most probable number per $100 \mathrm{ml}$ in the multiple tube fermentation technique of bacterial enumeration from the covered and open well water samples from the Bambui and Bambili residential areas are indicated in Table 1. The most probable number (MPN) per $100 \mathrm{ml}$ for the well water sample ranged between 3 and 1100+, which clearly exceeded the standard limit set by the World Health Organization (WHO [4] [5]). Table 2 shows bacterial pathogens isolated from well water from the Bambui and Bambili residential areas. Fifteen (80\%) well water samples from the tested locations were with two or more species of bacterial pathogens. Klebsiella sp. was predominant (73.3\%) in the well water samples, followed by Salmonella (66.7\%), Escherichia coli (53.3\%), Enterobacter species (26.7\%) and Proteus mirabilis (6.7\%). The distribution of organisms at the Bambui and Bambili residential areas can be seen on Figure 1 and Figure 2. It can be seen that fewer organisms were obtained from the covered wells (Figure 1), compared to open wells (Figure 2) that were more contaminated. Salmonella was absent in water samples W1C, W2C, W4O, W8O, W13C, W16O and W180. The distribution of organisms in covered and open wells samples (Table 2) showed that Salmonella sp. was encountered in 11 out of 18 samples from both covered and open wells making a percentage infection of $61 \%$. Its occurrence is greater in open wells than in the covered wells. The sanitary conditions of the open wells were poor due to growing vegetation around the wells and the use of dirty buckets to pull water from the wells while that of the covered wells were better improved than the open wells because of the cemented area around the wells and their covered nature. Meanwhile, in the two springs and three brooks, where water samples were collected and cultured, only one brook sample indicated the presence of Salmonella species, and one spring sample was positive for Klebsiella species.

\begin{tabular}{ll}
$\begin{array}{l}\text { Table } 1 . \text { Total bacteria viable count from well water samples in the Bambui } \\
\text { and Bambili residential areas. }\end{array}$ \\
\hline Samples & Total Bacteria Viable Counts cfu/ $\mathbf{m l} \times \mathbf{1 0} \mathbf{4}^{\mathbf{2}}$ \\
\hline W1C & 0.8 \\
W2C & 0.2 \\
W3C & 1.4 \\
W4O & 6.9 \\
W5O & 1.5 \\
W6C & 0.8 \\
W7O & 2.6 \\
W8O & 1.8 \\
W9O & 7.5 \\
W10O & 2.9 \\
W11O & 6.5 \\
W12O & 4.5 \\
W13C & 0.4 \\
W14O & 7.4 \\
W15C & 1.5 \\
W16O & 2.2 \\
W17C & 0.8 \\
W18O & 2.0 \\
\hline & \\
\hline & \\
\hline
\end{tabular}


Table 2. Distribution of bacterial pathogens isolated from water samples in the Bambui and Bambili residential areas.

\begin{tabular}{|c|c|}
\hline Sample & Isolates Identified \\
\hline W1C & Enterobacter species, E. coli \\
\hline $\mathrm{W} 2 \mathrm{C}$ & No growth \\
\hline W3C & Klebsiella species, Salmonella species \\
\hline W4O & Klebsiella species, Enterobacter species \\
\hline W50 & Escherichia coli, Klebsiella species, Salmonella species \\
\hline W6C & Klebsiella species, Salmonella species \\
\hline W7O & Escherichia coli, Klebsiella species, Salmonella species, Enterobacter sp. \\
\hline W80 & Escherichia coli, Enterobacter species \\
\hline W9O & Klebsiella species, Salmonella species \\
\hline W100 & Escherichia coli, Klebsiella species, Salmonella species \\
\hline W11O & Klebsiella species, Proteus mirabilis, Salmonella species \\
\hline W12O & Escherichia coli, Klebsiella species, Salmonella species \\
\hline W13C & No growth \\
\hline W140 & Escherichia coli, Klebsiella species, Salmonella species \\
\hline W15C & Escherichia coli, Klebsiella species, Salmonella species \\
\hline W160 & Klebsiella species, Escherichia coli \\
\hline W17C & Salmonella species, E coli \\
\hline W180 & Proteus mirabilis, Klebsiella species \\
\hline
\end{tabular}

Key: $\mathrm{W}=$ well water samples (numbered 1 to 18 ), $\mathrm{C}=$ water samples from covered wells, $\mathrm{O}=$ water samples from open wells.

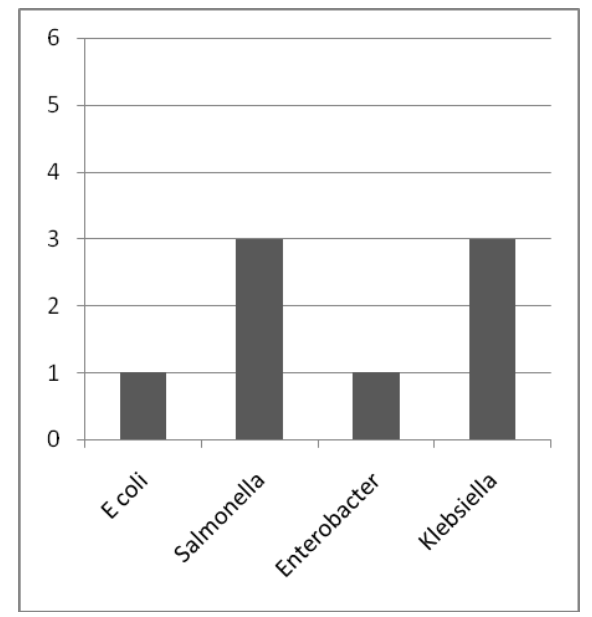

Figure 1. Distribution of organisms from covered wells.

\section{Discussion of Results}

The spread of diseases through faecal contamination of water sources particularly in developing countries are a common phenomenon that has been well reported. In the Bambui and Bambili residential areas as well as most parts of Cameroon, availability of treated pipe-borne water is rare and restricted where it exist to urban and semi-urban areas. Even in these areas, public water supply is quite irregular. Consequently, able individuals dig boreholes as alternative water sources. In fact, only $40 \%$ of Cameroonians have access to safe water [6]. The poor or average classes which constitute more than $80 \%$ of the population which cannot afford the high cost of 


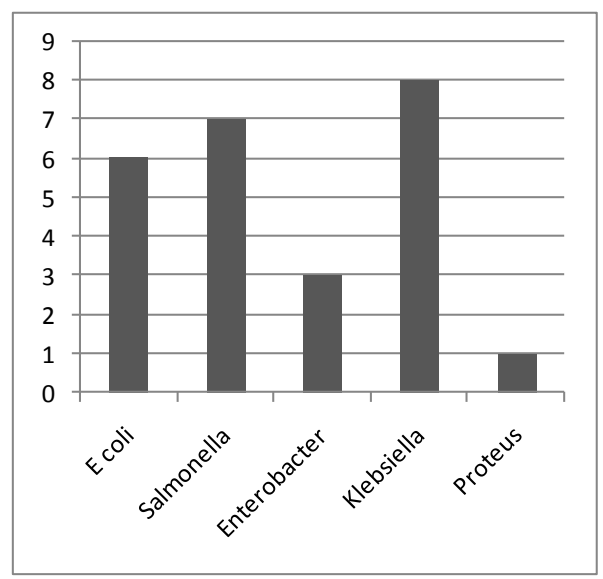

Figure 2. Distribution of organisms from open wells.

borehole drilling are forced to dig wells as alternative sources of water supply for drinking and domestic purposes, or rely on nearby springs and brooks. They often lack or cannot afford to hire experts in modern well construction that will normally apply standard techniques that will safeguard health, thus relying on rudimentary methods. The viable bacterial count which is a measure of the microbial load of the water sample obtained in this study $\left(0.2-7.4 \times 10^{4} \mathrm{cfu} / \mathrm{ml}\right)$ exceeded the recommended limit $(<500 \mathrm{cfu} / \mathrm{ml})$. This shows that the wells contain too high level of microbial contaminants that make water obtained from them a threat to public health. The values obtained for the samples from the open wells were higher than the ones from the covered wells. This is expected possibly due to the openness of the wells which permit unhindered access of particles from the surroundings compared to the covered wells. The most probable number (MPN) per $100 \mathrm{ml}$ obtained for the well water samples $(3-1100+)$ clearly exceeded standard limit set by WHO. This suggests that the well water samples have been contaminated by potentially dangerous microorganisms and is therefore not fit for drinking purposes. This was confirmed by the characterization of the isolates from the well water samples from the locations under study which were highly contaminated with several pathogenic microbes mainly of faecal origin. Any water source used for drinking or cleaning purposes should not contain any organism of faecal origin. Apart from environmental hygiene and population density, the presence of Salmonella species in some of the covered and open wells in this area may also be attributed to drainage and flooding from contaminated surface water into unprotected well shafts. This is in conformity with what [7] found in Papua New Guinea, but including irregular maintenance and compensation demands. Findings from this study clearly highlight the non conformity of well water samples studied with the WHO standard recommendation for safe potable water. A situation where enteric pathogens are grossly isolated from sources of water consumed by humans is a serious problem which calls for vigilance on the part of the authorities as it signals possible future outbreak of water borne diseases. Such disease outbreaks may spread widely within the country and even possibly extend to neighbouring countries since Cameroon shares boundaries with many West African states. Another reason for the gross contamination of well waters by pathogens observed in this study may be due to the shallow nature of the wells which allows easy entrance of particles from the surroundings. It may also be due to poor sanitary conditions around the areas where such wells are located or drawing water from the wells with contaminated containers, a practice that is common among the users since individuals bring along their own water containers in some cases. The high morbidity that is recorded from enteric diseases such as diarrhoea, dysentery and typhoid fever in the country may be due to widespread consumption of contaminated well water.

The findings of this study are comparable to that of a similar study carried out by [8] in Yaoundé town where Klebsiella sp. was the most predominant, (95\%) in the well water samples, followed by E. coli (72\%) and Salmonella sp. (32.5\%). All the open wells had the greatest contamination in the Bambui and Bambili residential areas. This is indicated on Table 3. The gross contamination of the open wells seen in this study is due to the easy access of bacteria and their spores into these wells. In either case, the covered wells had far less contamination than the open wells. Of course, they were protected from external contaminants. Finally, the high contamination rate of well waters by pathogenic organisms could be attributed to two main factors: Poor sanitary condi- 
Table 3. Organism distribution between covered wells and open wells.

\begin{tabular}{cc}
\hline Well Type & Organisms (Bacteria Species) \\
\hline Open wells & Salmonella sp., E. coli, Enterobacter sp., Klebsiella sp., Proteus mirabilis \\
Covered wells & Salmonella sp., E. coli, Enterobacter sp., Klebsiella sp. \\
\hline
\end{tabular}

tions and poor construction methods of wells. These problems are also seen to be common in other areas of Cameroon and other developing countries and if properly managed, then well water could be considered safe for drinking and used for other domestic purposes since soils here do not contain heavy metals, nor are agricultural activities practiced, where pesticide and chemical fertilizers use could introduce such metals in water.

\section{Conclusion}

This study examined the quality of water in a residential area and showed that there was a high incidence of contamination of well waters by pathogenic organisms. Sanitary conditions in and around the wells were found wanting, and so immediate intervention measures were strongly needed. To help ameliorate the situation, it is advocated that wells dug must be deep and covered adequately. Also good and proper personal and environmental sanitary practices must be maintained in and around the wells. Boiling well water before use for drinking purposes and also the use of filters would also go a long way to prevent incidence of waterborne diseases. Thus, water in the Bambui and Bambili residential neighbourhood is not safe for consumption, and so adequate treatment is strongly recommended. Based on the findings of this study, it is logical to suggest that regular water quality testing be implemented not only in these sites, but also in other neighbourhoods that are supplied with underground water. However, further research is needed to identify the origins of coliforms in these wells.

\section{References}

[1] World Health Organization (2004) Guidelines for Drinking Water Quality: Health Criteria and Other Support Information. 2, 18-97.

[2] United Nations (2008) The Millennium Development Goals Report. http://.mdgs.un.org.unsd/mdg/resources

[3] WHO/UNICEF (2000) Global Water Supply and Sanitation Assessment 2000 Report. United Nations Children’s Fund, and Water Supply and Sanitation Collaborative Council.

[4] World Health Organization (1997) Guidelines for Drinking-Water Quality: Surveillance and Control of Community Supplies. 3, 4-16, 96-219.

[5] Kingston, P.A. (2004) Surveillance of Drinking Water Quality in the Pacific Islands: Situation Analysis and Needs Assessment Country Reports. World Health Organization. (Accessed 19 June 2009). http://www.wpro.who.int/NR/rdonlyres/A363FA5A-E343-4DC9-90B2

[6] Samuel, M. (2011) Cameroon: How Affordable Is Potable Water for Communities? The Recorder News Online, Buea, Cameroon.

[7] WHO (World Health Organization) (2006) Guidelines for Drinking Water Quality: Incorporating First Addendum. 3rd Edition, WHO Press, Geneva.

[8] Nguedio-Yongsi, H.G. (2011) Microbiological Evaluation of Drinking Water in a Sub-Saharan Urban Community (Yaoundé). American journal of Biochemistry and Molecular Biology, 1, 68-81. 